\title{
Future of the Optometry Practice Lavenir de la pratique optométrique
}

\author{
by / par ALPHONSE CAREW, OD
}

$\mathrm{R}$ ecently I had an opportunity to consult with one of our national banks who were seeking information on how to provide enhanced services for independent professionals like optometrists. One question they asked was, what I felt the optometric practice would look like in 10 to 20 years from now. It was an interesting question that started me thinking about how the profession has changed in my more than 20 years of practice and how it will change in the next 20 years.

Some of the trends, like the expansion of our scope of practice to provide more therapeutic services will continue, but likely it will be simply tinkering at the edges of what most provinces allow now. I don't see major changes into surgical procedures or hospital based care being performed by optometrists to any significant extent. The independent, stand alone practitioner with the help of new, non-invasive, technology will however be able to diagnose and treat some of the common vision ailments we only deal with to a small extent today, like glaucoma and AMD.

Demographic changes with an aging population ensure that the need for our services will continue to be strong in the coming decades. It is estimated that in Canada the ophthalmologist-to-patient ratio will continue to fall in the foreseeable future, just as the population ages with increased incidence of eye diseases. Ophthalmology will be forced to concentrate on very specialized care leaving even more of their medical management to optometrists. Even now, government health care agencies and ophthalmologists are starting to recognize and support the importance of optometrists in the primary and secondary care of Canadians. Terms of reference for this care and the cooperation between the groups are being negotiated. This trend will continue resulting in more cooperative roles and more demand for optometric services over time.

Technology will allow relatively untrained assistants to capture patient information providing highly sensitive diagnosis by optometrists. Digital retinal imaging, the use of Optomaps, OCT's and HRT's have already greatly advanced our diagnostic power and we will see even greater enhancement of this in the future. The ophthalmic products we use in eye glasses and contact lenses will also steadily advance allowing for more options in perfecting vision. Considering the advancement in contact lens materials in recent years, one can envision a contact lens so biologically safe and acceptable for most eyes that the need for laser corrective surgery would be in doubt.

The optometric practice will likely trend towards more group settings as the most financially successful offices are those with three or more doctors. Also due to strong competitive forces that will only increase with time, I believe groups of practices (either city-wide, provincewide or nation-wide) will consolidate under one banner, or trade name. Ownership of these optometric focused chains will either be held by optometrists themselves or by other business partners as restrictions on association between doctors and corporations becomes more permissible or tested under freedom of association laws. To the public the distinction between corporate optical chains and optometric chains could become blurred as the physical set-up and marketing programs of both entities over time will appear similar. Both chains will learn the "best practices" of the other and will utilize highly trained staff with optometrists and opticians working together providing one-stop care from the eye exam to spectacles, contact lenses and laser surgery consultation with well-funded marketing programs. The consumer will be hard-pressed to tell the difference between the "chain" owned and operated by a business entity over one controlled by optometry. Whether this is good or bad for optometry depends on the penetration of optometry owned chains over corporate owned chains and how true they stay to the assumed superiority of an optometric based chain as a valid marketing position. 
In general, the financial health of the optometrist (especially those who are owners of a practice) will improve over time. High quality health care and products will always be desired by Canadians and will continue to be financed, either fully or partially, by provincial health care or third party insurance providers.

Without a doubt things will change greatly over the coming 20 years, as they have over the past 20 years. Some will be welcomed and some will be forced on the optometric practice. Progress will likely be at a slow pace as optometrists are conservative by nature, but rest assured it will come and it would be wise for optometrists to act proactively to take best advantage of these changes for their practices.
U ne de nos banques nationales nous a récemment consultés sur la façon de fournir des services améliorés à des professionnels indépendants comme les optométristes. L'une des questions qu'on m'a posées portait sur l'aspect que prendra, à mon avis, la pratique optométrique dans 10 ou 20 ans. Cette question intéressante m'a fait réfléchir à la façon dont la profession a évolué depuis que j'ai commencé à pratiquer il y a plus de 20 ans, et à la façon dont elle changera dans les 20 prochaines années.

Certaines tendances, comme l'expansion de notre domaine de pratique pour fournir davantage de services thérapeutiques, se poursuivront, mais ce seront vraisemblablement de simples retouches à la frontière de ce que la plupart des provinces autorisent à l'heure actuelle. Je

\section{THE SCHOOL OF OPTOMETRY AT THE UNIVERSITY OF WATERLOO IS SEEKING QUALIFIED OPTOMETRISTS FOR THE POSITION OF ASSOCIATE DIRECTOR FOR CLINICAL AFFAIRS.}

The successful applicant will also serve as Optometrist-inChief of the UW Optometry Clinic system and will report to the Director of the School of Optometry. The University of Waterloo Clinic system operates two major clinical facilities, one within the School of Optometry and the other (currently under construction) will be operated in conjunction with the Family Medicine Clinic affiliated with McMaster University's DeGroote School of Medicine, on the new UW Health Sciences Campus in Kitchener, Ontario.

The School of Optometry, the only English language School of Optometry in Canada, is in the midst of completing a $40,000 \mathrm{sq} f \mathrm{ft}$ addition that will allow for renovation of the UW School of Optometry Clinic and expansion of the TLC Laser Centre already on-site. UW also operates an extensive clinical outreach program, providing services to over 25 sites in the local Kitchener-Waterloo region. In addition to these UW clinical sites, the successful candidate will also oversee a large system of external placements, both in Canada and in the U.S., for 90 students per year.

Applicants are expected to have a distinguished record of teaching and patient care. Experience in patient-based research is desirable but is not essential. This person will oversee the operations of the entire UW Optometry clinic system and will be responsible for enhancing clinical education and training opportunities for both interns and residents. Previous administrative experience running an academic clinic is preferred. Experience at the interface between academic optometry and academic medicine is essential. A license to practice optometry in Ontario is desirable but is not required. The appointment to UW will be as a regular faculty member at an academic rank commensurate with the successful candidate's qualifications and experience. The scope of academic duties will be determined at that time.

Applications should include a detailed curriculum vitae, three confidential letters of reference, and a statement of capabilities and qualifications. Salary will be commensurate with experience. Send applications to:

Thomas F. Freddo, O.D., Ph.D., F.A.A.O.

Professor and Director

School of Optometry

University of Waterloo

200 University Ave., West

Waterloo, Ontario, CANADA N2L $3 G 1$

UNIVERSITY
OF WATERLOO

EDUCATION, EYECARE AND RESEARCH | FOUNDED IN 1967
C A N A D I A N J O UR R A L OF O P T O METR

$R$ E V U E C A N A D I E N N E D ' O P T O M É T R I E
Vol 71 No 3

Mai / mai 2009 
n'entrevois pas de grands changements dans les interventions chirurgicales ni dans les soins hospitaliers dispensés par les optométristes. Le praticien autonome et indépendant, avec l'aide d'une nouvelle technologie non invasive, sera cependant en mesure de diagnostiquer et de traiter une partie des troubles courants de la vision dont nous nous occupons que très peu aujourd'hui, comme le glaucome et la DMLA.

L'évolution démographique vers une population vieillissante garantit que nos services continueront d'être fortement demandés dans les décennies à venir. On prévoit que le rapport ophtalmologistes : patients au Canada continuera de régresser dans un avenir prévisible, tout comme la population vieillit en présentant une incidence accrue de maladies oculaires. L'ophtalmologie sera forcée de se concentrer sur des soins très spécialisés, laissant encore plus aux optométristes une partie des affections qu'ils prennent en charge. Même à l'heure actuelle, les organismes de soins de santé publics et les ophtalmologistes commencent à reconnaître et à appuyer l'importance des optométristes dans les soins de santé primaires et secondaires des Canadiens. Le mandat de ces soins et la collaboration entre les groupes font actuellement l'objet de négociations. Cette tendance se poursuivra et donnera naissance à une plus grande collaboration et à une demande accrue de services optométriques au fil du temps.

La technologie permettra à des adjoints relativement peu expérimentés de recueillir de l'information sur les patients afin que les optométristes puissent offrir des diagnostics très avancés. L'imagerie rétinienne numérique, l'Optomap, la TCO et la HRT ont déjà accru énormément notre capacité de diagnostic, et des perfectionnements encore plus avancés s'annoncent à cet égard. Les produits ophtalmiques que nous utilisons dans les verres et dans les lentilles cornéennes ne cessent de se raffiner et de perfectionner la vision. Compte tenu des progrès dans les matériaux des lentilles cornéennes depuis quelques années, on peut envisager une lentille cornéenne biologiquement sûre et acceptable pour la plupart des yeux à un point que la chirurgie corrective au laser risque d'être délaissée.

La pratique optométrique semble s'acheminer vers des regroupements encore plus nombreux puisque les cabinets les plus prospères sont ceux qui comptent trois optométristes ou plus. Vu également que la concurrence ne cessera de s'accroître avec le temps, je crois que des groupes de cabinets (urbains, provinciaux ou nationaux) fusionneront sous une bannière ou sous une appellation commerciale. Ces chaînes à vocation optométrique appartiendront soit à des optométristes, soit à d'autres partenaires commerciaux à mesure que les restrictions imposées aux associations entre les médecins et les sociétés seront davantage levées ou mises à l'épreuve aux termes de diverses lois sur la liberté d'association. Pour le public, la distinction entre les chaînes optiques et les chaînes optométriques pourrait devenir plus floue étant donné que la configuration matérielle et les programmes de commercialisation de ces deux entités prendront au fil des ans une apparence similaire. Ces deux types de chaînes adopteront les pratiques exemplaires de l'autre et leur personnel hautement qualifié travaillera de concert avec des optométristes et des opticiens à offrir un guichet unique pour les examens de la vue, les lunettes, les lentilles cornéennes et la chirurgie au laser, assortis de programmes de commercialisation bien nantis. Le consommateur aura bien du mal à faire la différence entre la « chaîne » possédée et exploitée par une entité commerciale et une autre contrôlée par l'optométrie. Que cela soit bon ou non pour l'optométrie dépendra de deux choses : la pénétration des chaînes appartenant à des optométristes par rapport aux chaînes appartenant à des sociétés, et l'importance qu'elles continueront d'accorder à la fausse supériorité d'une chaîne optométrique sur le marché.

En général, la santé financière de l'optométriste (surtout celui qui sera propriétaire d'un cabinet) s'améliorera avec le temps. Les produits et les soins de santé de haute qualité seront toujours au haut de la liste des Canadiens et continueront d'être financés en totalité ou en partie par un régime provincial ou par des assureurs tiers.

Il ne fait pas de doute que la situation évoluera beaucoup au cours des 20 prochaines années, tout comme elle l'a fait depuis 20 ans. Certaines choses seront bien accueillies et d'autres seront imposées à la pratique optométrique. Les progrès seront sans doute lents, car les optométristes ont une nature prudente, mais soyez certains qu'ils surviendront. Il serait sage que les optométristes agissent proactivement afin de profiter au maximum de ces changements dans leur pratique.

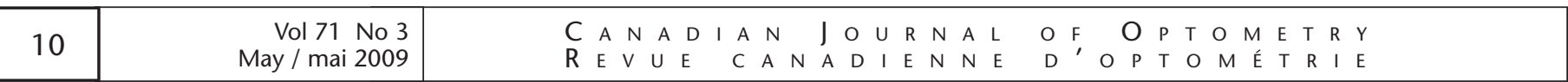

